\title{
ANÁLISE ESPACIAL DOS TECIDOS PRODUZIDOS PELO PROGRAMA MINHA CASA MINHA VIDA \\ O caso da Região Metropolitana de Natal/Brasil
}

\author{
Tamms Maria da Conceição Morais Campos \\ Universidade Federal Rural do Semi-Árido \\ Diretora de da Tese: Angela Lucia Ferreira \\ tamms.morais@ufersa.edu.br
}

\begin{abstract}
RESUMO
Observando o espaço urbano da RMN - Região Metropolitana de Natal/Brasil, constatou-se que algo diferente se instaura em seus tecidos urbanos, conduzindo a dinâmicos processos socioespaciais, que modificaram as tramas do seu território e delinearam desigualdades socioespaciais. Estes fatos nos levam a questionar: como a urbanização promovida pela dinâmica imobiliária residencial se materializa na (re) configuração da RMN? Quais formas e fenômenos territoriais se evidenciam neste processo de ocupação do solo metropolitano? De que maneira a intensidade da produção habitacional via Programa Minha Casa Minha Vida (PMCMV) se insere no redesenho da atual estrutura física da RMN? Buscar entender a lógica ocupacional e o processo de fragmentação do tecido urbano e desigualdade socioespacial por meio da produção recente de moradias na RMN é o objetivo deste artigo. O entendimento de toda esta conjuntura é explicado por meio do processo que aqui denominou-se "Urbanização Imobiliária Residencial".
\end{abstract}

Palavras chaves: Desigualdades socioespaciais, Programa Minha Casa Minha Vida, Urbanização Imobiliária Residencial

\begin{abstract}
By observing the urban space of the RMN - Metropolitan Region of Natal/Brazil, we noticed that something different was established in its urban fabrics that led to dynamic social-spatial processes, modifying the plots in its territory and outlining the socio-spatial inequalities. These facts lead us to question how the urbanization process, promoted by residential real estate dynamics, materializes in the (re)configuration of the RMN. What ways and territorial phenomena are evident in this metropolitan soil occupation? How does the intensity of housing production through the Minha Casa Minha Vida Program (PMCMV) fit into the current structure redesign of the RMN? To understand the occupational logic and the process of fragmentation of the urban fabric and socio-spatial inequality through the recent production of dwellings in RMN is the main goal of this article. The understanding of this entire conjuncture is explained through the process that is named here "Urbanização Imobiliária Residencial".
\end{abstract}

Key words: Socio-spatial inequalities, Minha Casa Minha Vida Program, Urbanização Imobiliária Residencial 


\section{CONTEXTUALIZAÇÃO}

Historicamente, o caso da Região Metropolitana de Natal (RMN), assim como o Brasil, viveu, nas últimas décadas, um aumento crescente do processo de urbanização com padrão descontínuo de expansão da mancha urbana e da concentração do contingente populacional que resultou em consideráveis modificações nas estruturas físicas, sociais e econômicas de suas cidades. O cenário decorrente desse processo tem se manifestado no padrão periférico de crescimento, comum nas cidades latinas com industrialização tardia, nas quais comportamentos especulativos prevaleceram sobre a função social do solo urbano e reforçaram sua baixa densidade de ocupação, além do aumento das distâncias, ineficiência dos transportes, elevação dos custos sociais e privados da urbanização e ineficácia da administração pública. Como consequência disso, a tendência ao maior crescimento demográfico nas áreas periurbanas ${ }^{1}$ em expansão ocasionou novas formas da produção do espaço urbano, que levaram a cidade para além de seus limites territoriais.

Na RMN dados preliminares vem mostrando que a ávida procura por solo apto a implantação de moradias pelo capital imobiliário, está gerando e/ou consolidando variantes na ocupação dos seus tecidos urbanos. Este fato nos leva a questionar: como a urbanização promovida pela atual dinâmica imobiliária residencial se materializa na (re) configuração da RMN? Além dessa questão central, surgem outras que a complementam: Quais as formas e os fenômenos territoriais se evidenciam neste processo de ocupação do solo metropolitano? De que maneira a intensidade da produção habitacional via Programa Minha Casa Minha Vida (PMCMV) se insere no redesenho da atual estrutura física da RMN?

Decorrem de evidência do processo de urbanização na RMN as seguintes hipóteses: a) a ocupação do território metropolitano pelos empreendimentos produzidos pela dinâmica imobiliária residencial vem dando continuidade a um processo que promove a "urbanização" 2 pontual e restrita, distribuída por meio dos investimentos do setor imobiliário, voltado para oferta de habitações no espaço urbano, ora "integrado" ora "desintegrado", dependendo da solvência dos adquirentes dos imóveis, a fim de garantir às famílias mais abastadas usufruírem das melhores localizações e infraestruturas instaladas; b) o processo de periferização ${ }^{3}$ residencial se firma num claro predomínio da baixa densidade e da habitação unifamiliar nos municípios da RMN que se distanciam de sua cidade-polo, apresentando uma dispersão urbana; enquanto que, os municípios do entorno imediato de Natal como Parnamirim e São Gonçalo do Amarante, apresentam predominância de tipologias compactas e verticais, devido, principalmente, a oferta do solo se apresentar escassa e seu valor alto; c) a fragmentação do território e a espacialização dos setores por meio da descentralização progressiva de urbanizações decorrentes da dinâmica resultante dos usos residenciais do tipo conjuntos habitacionais e condomínios (verticais e horizontais), contratados pela Caixa Econômica Federal (CEF) via Programa Minha Casa Minha Vida, desconectados do restante da trama urbana dos municípios.

Observa-se que processo de urbanização é complexo e as mudanças nos tecidos urbanos derivadas desse processo revelam uma ampla abrangência de atuação no capital imobiliário. Uma multiplicidade de formas de tecidos é produzida pelos empreendimentos imobiliários que envolvem uma variedade de usos como hotelaria, serviços, lazer, indústria, comércio (desde shoppings centers a supermercados varejistas e atacadistas), entre outros, além das mais variadas combinações. Dentre esses setores, optou-se por estudar aquele que mais interfere no processo atual de (re) configuração da RMN, o uso residencial, composto pelos conjuntos habitacionais (loteamentos de casas) e condomínios fechados (horizontais e verticais), tipologias estas mais representativas do território metropolitano e que, no período de levantamento de dados desta pesquisa, estava sendo promovido com mais intensidade pelo PMCMV. As análises das características foram realizadas no nível de ocorrência: a do tecido urbano, das formas de dispersão metropolitana, da análise considerada inter-regional, a mais ampla, e que abrange todos os municípios da RMN. Assim, fez-se o registro da análise de empreendimentos em grande escala, sob as formas condominiais e de loteamentos, a fim de comprovar o processo de configuração da RMN como um todo.

\footnotetext{
${ }^{1}$ De acordo com Dematteis (1998 apud Sposito, 2007, p.12) este tema de periurbanização "consiste na recuperação da polarização urbana que agora, ao contrário, manifesta-se como dilatação progressiva das coroas externas e das ramificações radiais dos sistemas urbanos com redução tendencial dos núcleos urbanos".

${ }^{2} \mathrm{O}$ conceito de urbanização presente neste artigo está sendo utilizado em dois significados diferentes expostos por Reis (2006, p. 47), ou seja, "no sentido físico, de extensão do tecido urbano, como ampliação de terrenos urbanizados e no sentido de processo social e demográfico de urbanização, de transferência de população rural para áreas urbanas, adoção de modos de vida urbanos e metropolitanos, em áreas densas e dispersas". Espera-se que o sentido fique claro em cada um dos casos em que o utiliza.

${ }_{3}^{3}$ Aqui utiliza-se no sentido mais genérico de crescimento urbano das periferias, pois essa é a aceitação mais tradicional tanto nos EUA como na Europa.
} 
Vale ressaltar que existem outras modalidades de utilização do PMCMV no restante da RMN, seja por meio de financiamentos do imóvel já construído seja pela modalidade de produção de imóvel por bancos privados. Esses casos não foram tratados neste artigo, somente os casos de produção de imóveis novos contratados pela Caixa Econômica Federal entre Agosto de 2009 a Junho de 2014, referente a 174 empreendimentos (imóveis urbanos e rurais), correspondendo a um total de 21.679 unidades habitacionais ofertadas por Programa na RMN. As análises de fontes primárias e de campo se dirigiam tendo como foco: para desvendar o processo de ocupação da RMN; a produção do PMCMV 1 e $2^{4}$, e dos fatores determinantes na interpretação de processos urbanos detectados empiricamente; a qualidade urbanística da produção atual do PMCMV destinada às duas faixas de renda 01 e 02 , até $R \$ 1.600,00$ e até $R \$ 5.000,00$, respectivamente.

Outro motivo de ordem teórica é deixar registrada uma pesquisa cujo foco é voltado para o olhar crítico sobre a inserção urbana dos empreendimentos que o programa PMCMV abarca. Estudos como este são necessários como ponto de partida para não somente a elaboração de políticas públicas no setor de planejamento urbano, como planos e programas habitacionais mais precisamente para a elaboração de uma política de reestruturação que pretenda impactar concreta e profundamente o modelo de cidade há muito instaurado, ou seja, que contribua para o debate da apropriação classista dos benefícios de uma boa localização e que propicie a ampliação do acesso equitativo aos recursos urbanos bem como a moradia digna.

Levou-se em conta ainda, a necessidade de se reconstituir o processo de urbanização da RMN com base nos antecedentes da dinâmica de ocupação pelo setor imobiliário residencial promovida pela atuação do BNH, na década de 1964, aos dias atuais correspondendo ao Programa Minha Casa Minha Vida, inserindo tal atuação como o grande precursor do esgarçamento da malha urbana de Natal juntamente com o processo do "imobiliário turístico", conceito utilizado por Silva (2010), nos municípios da borda litorânea da RMN. Acrescenta-se que para o enquadramento do universo de estudo levou-se em conta a estrutura metropolitana da RMN que foi apontada por Clementino e Pessoa (2009a) como uma "metrópole em formação", e que recentemente com os estudos do Observatório das Metrópoles/Natal/Brasil, sobre os dados atualizados do Censo de 2010, foi definida como sendo uma "área urbana metropolizada pelos resultados de uma reestruturação produtiva incentivada pelo Estado e por uma economia subsidiada por fortes investimentos públicos em infraestrutura (...)", (Duarte et al., 2015, p.420), coexistindo a "metrópole funcional e a metrópole institucional" conforme Clementino et. al (2015, p. 420).

As principais fontes de dados foram as informações coletadas nas instituições assinaladas: as Prefeituras e suas respectivas secretarias de licenciamento ambiental e urbanístico das cidades envolvidas, Secretaria de Estado do Trabalho, da Habitação e da Assistência Social (SETHAS/Natal), a Caixa Econômica Federal, Instituto Nacional de Pesquisas Espaciais (INPE), Instituto de Desenvolvimento Sustentável e Meio Ambiente (IDEMA), Secretaria de Meio Ambiente e Urbanismo de Natal (SEMURB), Instituto Brasileiro de Geografia e Estatística (IBGE) - 2010, Sistema Eletrônico de Serviço de Informação ao Cidadão (e-SIC) referente aos contratos realizados pela Caixa Econômica Federal (CEF) via PMCMV, entre 2009 a 2014, como dito anteriormente, e Observatório das Metrópoles. Deve-se ressaltar também a pesquisa em fontes estatísticas do Instituto Brasileiro de Geografia e Estatística (IBGE). Por meio desses dados foram obtidas as informações dos tipos de programas enquadrados pela faixa de renda, o número de habitações construídas, a localização, valores implicados, modalidades de financiamento, perfil da população beneficiada. Também fez parte da pesquisa de campo, o levantamento fotográfico da produção local (observando-se principalmente a inserção urbana).

O presente artigo se estrutura em duas partes em decorrência da aproximação com as hipóteses levantadas. A primeira parte está relacionada à análise sobre a conformação urbana da RMN, delineando as formas de ocupações e relacionando-as com os processos e as formas resultantes; e a segunda parte, compreende a análise da fragmentação e espacialização dos setores conformados pelos aspectos gerais do PMCMV e as características de sua inserção na Região Metropolitana de Natal, avaliando o estudo das áreas produzidas e sua relação com o tecido urbano, como poderá ser visto a seguir.

\footnotetext{
${ }^{4}$ O Programa Minha Casa Minha Vida, correspondeu inicialmente à Lei Federal 11.977/09 alterada pela Medida Provisória 514/2010 e pelas leis 12.249/2010, 12.350/2010 e 12.424/2011. A Lei 12.424 de 16 de junho de 2011, que revogou e alterou diversos artigos da Lei 11.977/09, ficou conhecida como Lei do PMCMV 2 por redefinir diversos parâmetros que regem o programa, assim como a meta referente ao número de unidades a serem produzidas. Em seus Art. $1^{\circ}$ das Leis 11.977/2009 e 12.424/20114, preveem a requalificação de imóveis urbanos, no entanto, dentro da dinâmica imobiliária do Brasil, a grande participação do mercado está sendo voltada para a construção de novas unidades habitacionais.
} 


\section{PROCESSOS E FORMAS DE TRANSFORMAÇÃO TERRITORIAL (1964-2014) DA REGIÃO METROPOLITANA DE NATAL/BRASIL}

Desde a década de 1960, com o início da política habitacional do Banco Nacional de Habitação (BNH) ${ }^{5}$, posteriormente com o imobiliário turístico no início do século XXI e, atualmente com o Programa Minha Casa Minha Vida (PMCMV), o território que hoje compõe a Região Metropolitana de Natal-Brasil foi submetido a diversas mudanças, de maior ou menor alcance que em sua dinâmica de crescimento configuram formas de ocupação diferenciadas. A seguir identifica os principais processos de estruturação territorial da Região Metropolitana de Natal - RMN, (Figura 1) e a materialização (formas) no seu arranjo espacial metropolitano com base em alguns autores locais, como: (Clementino, 2009a, 2009b) e (Ferreira, 1996); e também com base na análise da ocupação do tecido urbano metropolitano por meio, principalmente, da dinâmica imobiliária residencial.

As características dominantes das etapas significativas no processo de formação do território da RMN, principalmente com relação a sua cidade-polo, Natal, sobre o território, são caracterizadas por:

a) 1964-1986: período marcado pela industrialização moderna, boom imobiliário e a descentralização residencial. Traz o período de autarquia econômica posterior à guerra civil e à industrialização do país que contribuiu para a expansão de grandes e médias cidades no país, assim como para a formação no que vai ser reconhecida posteriormente como RMN (ver figura a seguir), comportando importantes demandas urbanas dos mais variados tipos e correntes migratórias iniciadas na década de 1940 pelas atividades estratégicamilitares com a implantação da Base Aérea Norteamericana nos municípios de Parnamirim e Natal. As necessidades residenciais provocaram um grande boom imobiliário, responsável pela formação de "periferias urbanas invertebradas" ${ }^{6}$, por meio dos processos de densificação das áreas suburbanas, dos bairros de urbanização periférica e dos conjuntos habitacionais populares, dotados de espaços livres precários, equipamentos, infraestrutura, transporte, dentre outros.

Nesse período a intervenção do Estado no mercado imobiliário proporcionou a segregação socioespacial pela política do $\mathrm{BNH}$ e a urbanização dispersa e fragmentada do território, na medida em que promoveu a transformação do solo rural em urbano e a expansão de um modelo de ocupação extensiva. Produziu-se também a transformação progressiva da estrutura econômica da região, por meio das atividades industriais e do setor dos serviços relacionados ao turismo que se alavancou, que por sua vez, deu início a urbanização de segundas residências, isto é, domicílios produzidos para temporadas turísticas e do espraiamento territorial da RMN. Diante dessa conjuntura, surgiram os primeiros indícios da má distribuição não somente de infraestrutura e urbanização como na má distribuição espacial em seu território, através do esgarçamento dos tecidos urbanos construídos.

b) 1987-2008: Esse período é marcado pela grande transformação no território litorâneo da RMN, que se pode chamar urbanização para o turismo. De todos os intervalos temporais elencados neste item, esse se destaca devido à consolidação dos municípios litorâneos na dinâmica imobiliária residencial atuando no cenário metropolitano. Além dos municípios de Natal e Parnamirim, se destaca os municípios de Ceará-Mirim, Extremoz e Nísia Floresta (ver a seguir). Esse fato é decorrente principalmente da atividade turística que foi incentivada a partir de 1995 com o lançamento do Programa de Desenvolvimento Turístico no Nordeste (PRODETUR/NE), que por meio de diversos incentivos a serem empregados fundamentalmente para 0 desenvolvimento institucional (reorganização de secretarias, elaboração de base cartográfica e planos diretores), instalação de infraestrutura e ampliação e modernização do aeroporto. Com essa "alavancada" na infraestrutura, e a propaganda de turismo de sol e mar, o aumento do número de turistas nacionais e internacionais, a construção e extensão da malha urbana chegando principalmente nos municípios litorâneos metropolitanos, favoreceram assim, o espraiamento do tecido urbano metropolitano juntamente com a atuação da urbanização promovida pelo capital imobiliário voltado ao uso residencial.

\footnotetext{
${ }^{5}$ Esse período teve um marco importante em todo o Brasil, que interfere no processo de construção das cidades brasileiras, é a Política Nacional de Habitação implantada pelo regime militar, a partir de 1964. Esta política dirigida pelo BNH (Banco Nacional de Habitação) era realizada por meio de seus agentes promotores como as COHAB`s (Companhias Habitacionais) e pelo INOCOOP (Instituto Nacional de Orientação às Cooperativas).

${ }^{6}$ Referência de definição utilizada por Font (2012) para o caso do território metropolitano de Barcelona-Espanha, mas que se aproxima com o que o artigo trata para a tais municípios da RMN.
} 


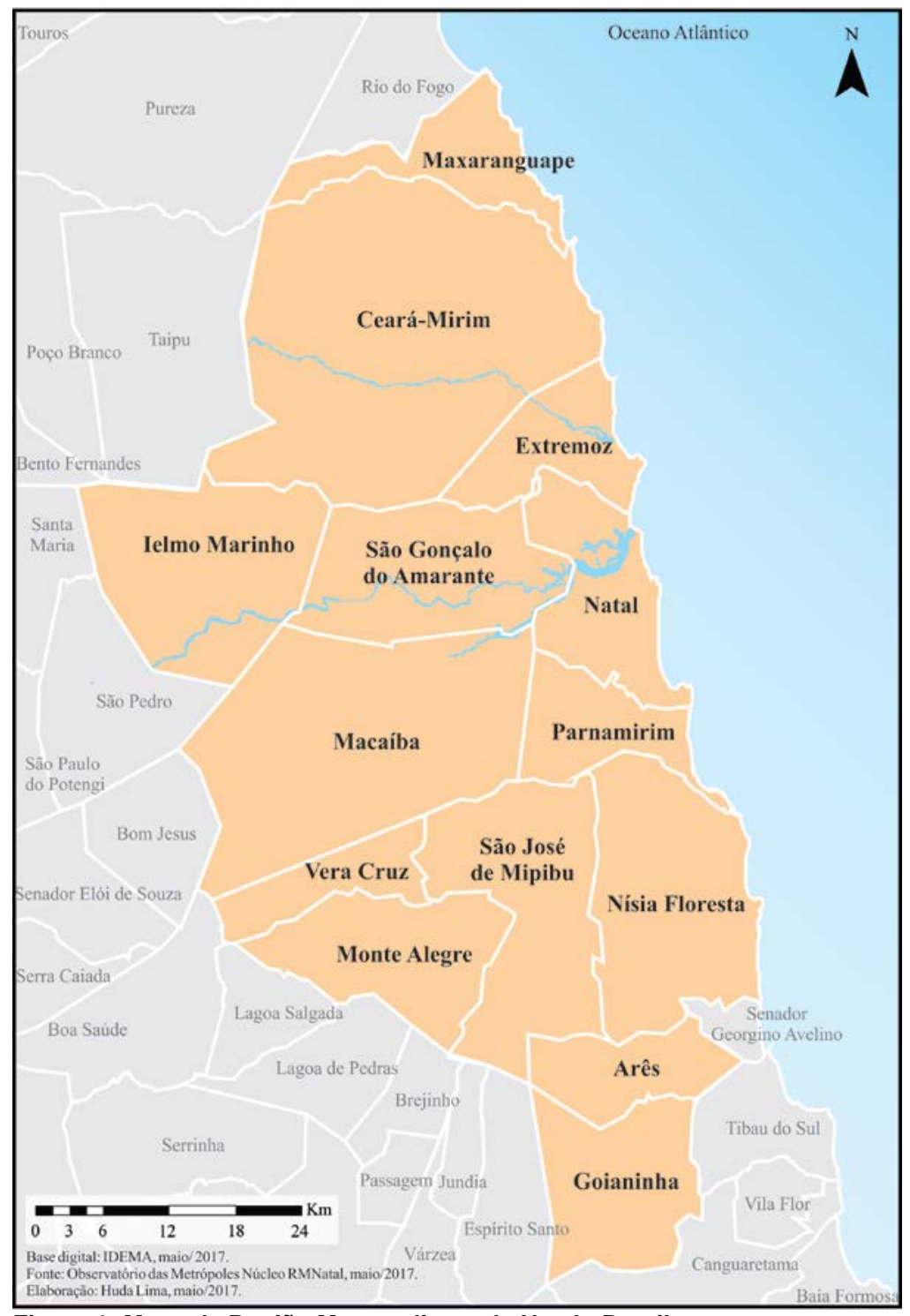

Figura 1: Mapa da Região Metropolitana de Natal - Brasil.

Fonte: Observatório das Metrópoles Núcleo RMNatal, Maio 2017. Elaboração: Huda Lima (2017).

A descentralização que iniciou no período anterior provocada pela atividade turística a partir da década de 1990 foi efetiva tendo em vista que, enquanto a maioria das atividades econômicas se desenvolvia no Polo Metropolitano de Natal, o turismo se desenvolvia a partir de atrativos naturais presentes nos municípios vizinhos litorâneos do seu entorno, com destaque para Parnamirim, Nísia Floresta, Extremoz e Ceará-Mirim (ver Figura 1). O cruzamento dos investimentos públicos com os privados nas capitais nordestinas implica, na inserção de Natal, como um cenário das principais destinações turísticas do País, sendo indicadas, em pesquisa realizada pela EMBRATUR, entre as quinze cidades mais visitadas nos anos de 2004 e 2005 . De acordo com Silva e Ferreira (2012, p. 144) a dinâmica imobiliária "entre 2001 e 2006, foi sistematizada e especializada para os municípios da RMN, especificamente os litorâneos". Esse processo, denominado por Silva (2010) como "imobiliário turístico", estava "longe de ser "natural" de oferta e demanda e sim uma articulação entre interesses fundiários, investidores de capital e planejamento público", o que resultou na transformação do território, principalmente na orla costeira da RMN. Portanto, essa curta fase da dinâmica imobiliária passou a pressionar o valor do solo na RMN, no momento não mais concentrado em bairros, mas sim em uma mancha de expansão ao sul e ao norte, sentido litoral.

O espraiamento desta mancha urbana pelo território costeiro foi atingido em 2008 pela a crise financeira com participação de bancos e de empresas de capital aberto - no processo especulativo que abrangeu a RMN entre 2003 e 2008. Essa crise internacional passa a influenciar a conjuntura econômica do país e, consequentemente a da RMN, à decisão do Governo em combatê-la, privilegia o setor da construção civil, dando o impulso suficiente para a constituição do Programa "Minha Casa, Minha Vida". 
c) 2008-2014: Após a crise mundial que explodiu entre os anos de 2007-2008, onde as implicações na economia européia somou-se a chegada em 2009 dos financiamentos do PMCMV pelo Governo Federal a produção imobiliária foi estendida a outros setores e demandas da RMN. Até então a ocupação vinculada ao turismo vinha se concentrando na faixa costeira e sustentada por meio de investimentos estrangeiros. Esta transformação na dinâmica do mercado imobiliário proveniente da retração do capital estrangeiro que se deu paralelo a incidência do PMCMV estimulou o crédito imobiliário e proporcionou ao mercado maior capacidade de liquidez (Observatório das Metrópoles, 2012).

A partir deste momento, o setor imobiliário, se beneficiou não somente dos novos recursos advindos do financiamento público do Programa Minha Casa Minha Vida, mas também da criação de novas áreas urbanizadas minimamente qualificadas pelas construtoras participantes do Programa e/ou má distribuídas no território pelos processos de redefinições de usos e ocupações do espaço a partir de sua instrumentalização, voltada para assegurar rentabilidades capitalistas cada vez maiores, configurando assim a "Urbanização promovida pelo PMCMV". Os eixos de expansão ganham nova expressividade a partir de Natal no sentido da conurbação com o município de Parnamirim, do transbordamento do seu limite físico norte com São Gonçalo do Amarante - e em direção aos demais como Macaíba, Ceará-Mirim e Extremoz (ver Figura 1), ocasionando o processo de interiorização da mancha de ocupação da RMN.

Esse momento de novos processos de articulação e dinâmica urbana na RMN se dá ademais do Programa Minha Casa Minha Vida, no âmbito habitacional, pela emergência de políticas públicas federais como o Programa de Aceleração de Crescimento (PAC) ${ }^{7}$, de abrangência em infraestrutura. Esses processos giram em torno da espacialização dos investimentos no setor imobiliário no espaço urbano ora "integrado" ora "desintegrado" dependendo da solvência dos adquirentes dos imóveis, caracterizando a dinâmica atual da produção imobiliária residencial. Diferentemente da fase anterior pelo imobiliário-turístico que representava uma emergência do poder local (estadual e municipal), adotando e melhorando a infraestrutura turística por meio do PRODETUR I e II, o PMCMV está estimulando o crédito imobiliário e favorecendo ao mercado maior capacidade de liquidez. Assim, está ocorrendo a mudança de foco na promoção imobiliária que passou de ter um turista internacional como preferência de comprador para focar nas classes nacionais de menor renda.

O fenômeno de esgarçamento do tecido urbano foi determinante para aproximar Natal do restante dos outros municípios da RMN e consequentemente para este processo de metropolização desta Região, marcado pela dinâmica de ocupação promovida pelo capital imobiliário residencial, onde o direcionamento da instalação de infraestrutura e a urbanização se deram diferenciados no espaço, conformando a fragmentação espacial e desigualdade social, deixando um padrão de rupturas no território, marcado por tecidos urbanos homogêneos conformados pela escala de grande produção de habitações repetidas e pela morfologia fragmentada. A lógica do ordenamento territorial da produção imobiliária residencial tem como consequência a hipervalorização dos espaços de moradia localizados nas áreas urbanizadas, como acontece no município de Natal e Parnamirim, principalmente, enquanto nas áreas urbanas, a criação de novas áreas residenciais com o mínimo de infraestrutura, como é o caso dos municípios de Extremoz, Ceará-Mirim e Macaíba.

Diante desse contexto, verificou-se que se formaram três coroas urbanas, ou seja, áreas resultantes do processo de ocupação, no caso da RMN, se deram principalmente em função dos momentos de expansão da produção imobiliária residencial tendo como eixos delimitadores três momentos marcantes: a ocupação do território pela política habitacional do $\mathrm{BNH}$, em um segundo momento com o imobiliário turístico e atualmente com o PMCMV, Figura 4.

\footnotetext{
${ }^{7}$ Instituído pelo Decreto $n^{\circ} 6.025$, de 22 de Janeiro de 2007 , no qual de acordo com seu Art. $1^{\circ}$ é constituído de medidas de estímulo ao investimento privado, ampliação dos investimentos públicos em infraestrutura e voltadas à melhoria da qualidade do gasto público e ao controle da expansão dos gastos correntes no âmbito da Administração Pública Federal.
} 


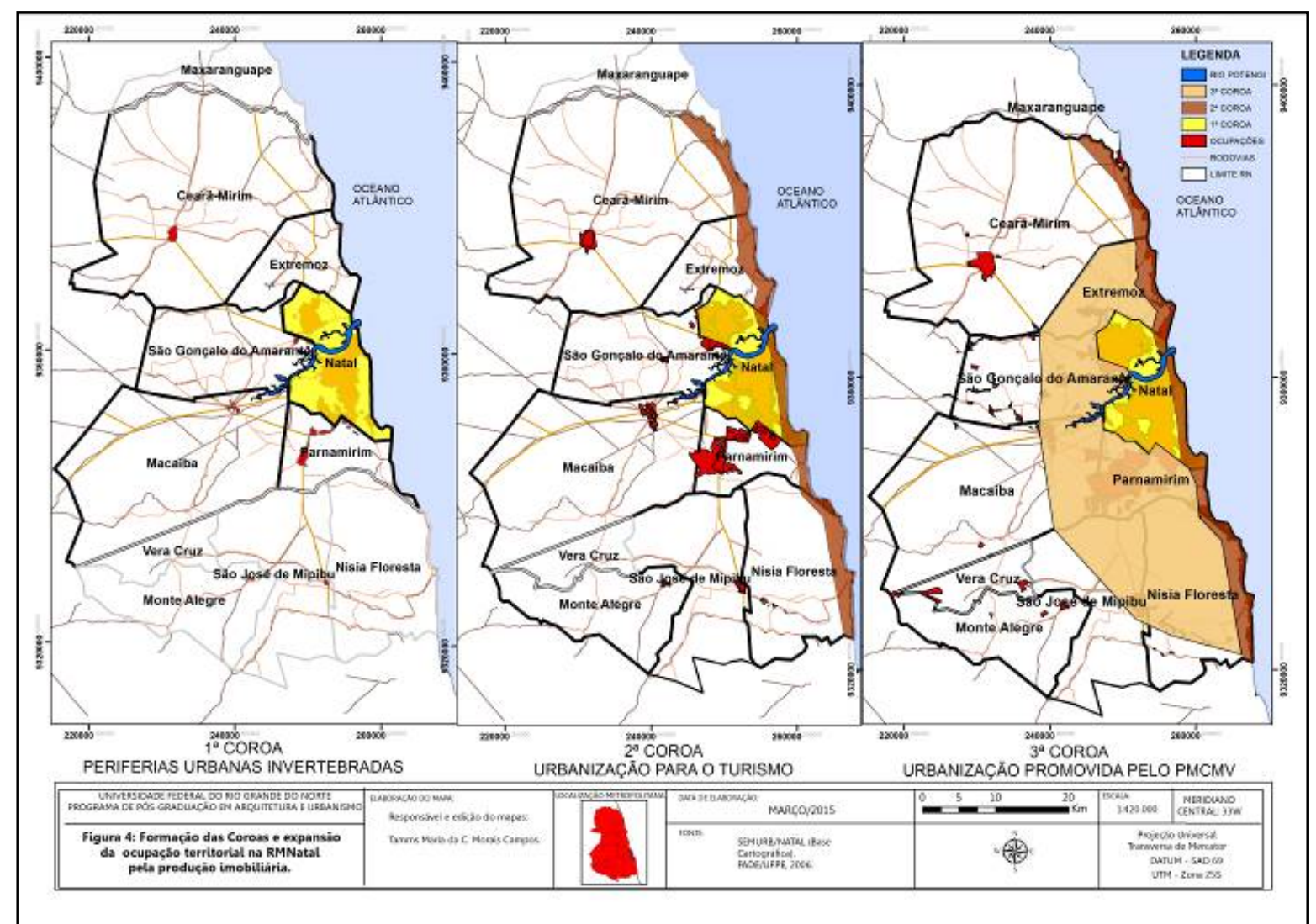

Figura 2: Formação das coroas urbanas e expansão da ocupação territorial na RMN pela produção imobiliária. Fonte: Observatório das Metrópoles/ Núcleo RMN processada pelo INPE, 2006. Nota: elaboração própria, 2014.

Resumidamente, no contexto da RMN sua expansão do tecido urbano se deu primeiramente com a "descentralização das residências" produzidas pela política de habitação do BNH (1964-1986) formando a "1a Coroa", posteriormente com a difusão das segundas residências atuando como atividade turística no litoral Potiguar por meio do Imobiliário Turístico formando a "2a Coroa" e atualmente com a "urbanização promovida pelo PMCMV" constituindo a "3a Coroa", Figura 2, consolidando nessas três etapas a formação do processo de expansão da ocupação da produção imobiliária residencial presente ao longo desses anos na RMN e visto notoriamente na Área Metropolitana Funcional ${ }^{8}$ de acordo com a integração da trama urbana dos municípios de Natal, Parnamirim e São Gonçalo do Amarante. Percebe-se que a $1^{\text {a }}$ Coroa é constituída pela cidade-polo Natal, cuja expansão da ocupação se deu pelo esgarçamento de seu interior, formando suas "Periferias urbanas Invertebradas", caracterizadas pela urbanização das áreas periféricas pela implantação dos conjuntos habitacionais do BNH entre as décadas de 1964 a 1986 . Esses elementos foram determinantes para a definição do crescimento periférico que influenciou significativamente os limites territoriais com a orientação de expansão para o Sul e para o Norte/Noroeste veio rapidamente a esgotar o território da cidade Capital, aproximando-se dos limites municipais com Parnamirim pelos indícios do processo de conurbação, com São Gonçalo do Amarante e com Extremoz, esses dois últimos pelo transbordamento de ambos os limites territoriais municipais.

A $2^{a}$ Coroa, formada pelo imobiliário turístico apresenta um formato linear, devido ser uma faixa paralela à orla marítima que se inicia em Nísia Floresta e segue até Ceará-Mirim e Maxaranguape, abrangendo onde hoje inserem-se os municípios litorâneos da RMN. Neste período, o tecido urbano costeiro sofreu esgarçamento e aumentou a densidade de ocupação ao longo de toda a costa litorânea. Silva (2010, p. 8) observa que neste momento "ocorre uma integração regional como expressão da expansão da mancha

\footnotetext{
${ }^{8}$ Corresponde a escala intraurbana do território metropolitano aqui analisada e constituída pelos municípios de Natal, Parnamirim e São Gonçalo do Amarante. Aproxima-se do que Font (1997, p. 16) define para o caso da Região Metropolitana de Barcelona e que se aplica para o caso de Natal, relativizando os contextos políticos, econômicos e sociais, como sendo: Um sistema urbano polinuclear extendido pelo território, fragmentado e descontínuo, no qual recentemente a população e uma boa parte da atividade produtiva e dos serviços pessoais tendem a difundir-se pelo território alterando o modelo tradicional de aglomerado ou cidade contínua com dependências quase exclusivas do núcleo central, em um território hierarquizado, porém mais interativo e auto organizativo e de grande heterogeneidade morfológica (tradução nossa, p.16).
} 
urbana metropolitana de Natal". As mudanças na conjuntura internacional fizeram mudar a dinâmica do mercado imobiliário na cidade por meio da produção em larga escala das segundas residências e instalações de megaempreendimentos de hospedagens, resorts e condomínios, com interferência nos efeitos socioespaciais na metrópole natalense, advindos da intensificação do imobiliário turístico sobre o território metropolitano e para além deste. Isso resultou a valorização da orla marítima, modificando o território costeiro da RMN em locais de recepção e de distribuição de fluxos turísticos e, colocando as sedes municipais muitas vezes sem ganhos diretos - em uma posição de dependência da dinâmica imobiliária e turística, guiada especialmente pelo capital internacional, em suas praias.

Com isso, veio a formação da $3^{a}$ Coroa na RMN, onde se verifica a extensificação da urbanização para o interior da RMN, Figura 2, a qual representa o espraiamento do tecido urbano da Região por meio da transformação de solo urbano para rural, com tendência ao crescimento periférico principalmente nos municípios da RMN mais distantes da cidade-polo Natal. Constatou-se que as formas de ocupações implantadas pelos empreendimentos do PMCMV, estão atuando no processo de fragmentação do território metropolitano, assim como ocorreu à política habitacional do $\mathrm{BNH}$, isto é, diferenciando o espaço físico em função da renda solvável e consolidando a má distribuição de urbanizações e infraestruturas, características da produção imobiliária residencial de baixa renda.

Como pode ser visto, a expansão urbana da RMN por meio da atuação da política habitacional do PMCMV está provocando uma interiorização no sentido de ocupar as franjas da Região Metropolitana de Natal esgarçando o tecido urbano e fragmentando o território. Essa nova feição morfológica, produto dos novos caminhos da produção imobiliária pós-crise, mas também de momentos anteriores, causou outro padrão de ocupação que se conforma em um espraiamento do processo de metropolização com tecidos urbanos bem definidos pela produção de larga escala conformada pelo pela atual urbanização promovida pelo capital imobiliário residencial. Para a análise da referida forma de ocupação, faz-se necessário o estudo dos tecidos produzidos pelo PMCMV e o modelo explicativo que conforma o processo atual de (re) configuração da RMN, que será analisado a seguir.

\section{EM RELAÇÃO AO SISTEMA URBANO}

Para melhor entender os processos e as formas urbanas da RMN, levou-se em consideração a distância da cidade-polo, Natal, por se tratar de um núcleo urbano que historicamente deu início à constituição desta Região Metropolitana. Para tanto, analisou-se o que diz respeito ao sistema urbano, com base em Font (2012), o qual refere-se ao estudo das áreas produzidas e sua relação com o tecido urbano, que nos permitiu estabelecer quatro tipos de setores - integrados, em continuidade, dispersos e segregados - no caso da RMN foram enquadrados e analisados a seguir. Portanto, a análise apreendida nesse item sobre os Sistemas Urbanos é espacial e urbanística, ou seja, leva em consideração elementos que identifiquem a espacialidade dos empreendimentos e seus tecidos produzidos, sem contudo, analisar os elementos tipológicos de constituição das edificações como muros, barreiras físicas ou soluções arquitetônicas.

\subsection{Setores Integrados}

São aqueles que estão integrados em tecidos urbanos muito consolidados e com certa densidade. Font (2012) analisa o caso da Região Metropolitana de Barcelona/Espanha e define como aqueles polígonos que cresceram em seu núcleo histórico, no qual ocorreu mudança em seu uso que passou progressivamente de ser industrial a ter caráter terciário, por exemplo. Especificamente em Natal "não identifica-se áreas industriais específicas" (Natal, 2007, p. 127), porém, há áreas pontuais nesta cidade que sofreram transformação de uso, por exemplo, a Ribeira, bairro histórico da cidade de Natal, onde havia presença de "tecidos industriais históricos", denominação utilizada por Font (2012, p. 46), e que ao longo da evolução urbana da cidade foi substituído pelo uso de comércio e serviços.

No caso de Natal houve quase que um deslocamento das atividades de comércio, lazer e serviços em direção a zona sul nos últimos anos comprometendo o uso e a funcionalidade urbana e mesmo a paisagem dos tradicionais bairros comerciais. O velho centro perdeu centralidade, novos bairros surgiram e talvez somente o velho bairro do Alecrim seja, ainda, aquele que mantém sua condição anterior de centro de comércio popular. Por outro lado, a revalorização do solo e das propriedades imobiliárias em certos bairros nobres como Tirol e Petrópolis e em certas zonas - como a Zona Sul de Natal - podem modificar os adensamentos populacionais e redirecionar os investimentos imobiliários residenciais, públicos ou empresariais, conformando novos bairros ou redefinido ocupação. 
A seguir, estão listados os empreendimentos que se enquadram, conforme esta caracterização supracitada, como sendo Integrados, ou seja, todos aqueles inseridos na cidade-pólo, Natal.

\begin{tabular}{|l|l|l|l|}
\hline $\begin{array}{l}\text { Sistema Urbano } \\
\text { Integrado }\end{array}$ & $\begin{array}{l}\text { Faixa 01 (Até R\$ } \\
1.600,00)\end{array}$ & $\begin{array}{l}\text { Faixa 02 (Até R\$ } \\
5.000,00)\end{array}$ & Município \\
\hline $\begin{array}{l}\text { Quantidade } \\
\text { (Empreendimentos) }\end{array}$ & 04 & 21 & Total: 25 \\
\hline $\begin{array}{l}\text { Quantidade (Unidades } \\
\text { Habitacionais) }\end{array}$ & 896 & 2.956 & Total: 3.852 \\
\hline
\end{tabular}

Quadro 1: Empreendimentos financiados pela CEF, via Programa Minha Casa Minha Vida, enquadrados no Setor Integrado. Fonte: Elaboração própria, 2015. Base de dados: E-sic, 2012/2013/2014.

Dos 25 (vinte e cinco) empreendimentos presentes em Natal, 71\% estão localizados na Zona Administrativa Oeste. Os tecidos urbanos correspondentes a esta zona não sofreram alterações de uso, mas apresentamse inseridos nesse setor integrado por meio da presença de infraestrutura instalada, tecidos urbanos consolidados, comprovado pelo seu processo de evolução urbana histórica, densidade elevada acima de $4.800 \mathrm{Hab} / \mathrm{Ha}$ e intensa ocupação urbana, características, estas, presentes apenas na cidade-polo, Natal. Por isso, na RMN, Natal é a única cidade que se enquadra nesse setor. Constata-se que desse total de 25 empreendimentos, $95 \%$ é destinado a faixa 02 de renda, ou seja, a implantação de empreendimentos pelo PMCMV contratados pela CEF no setor integrado, onde há presença de infraestrutura básica instalada, viabilizou o acesso à população com renda até $R \$ 5.000,00$, e o da faixa 01 de renda, somente teve acesso, na periferia do bairro Guarapes, no caso do Residencial Vivendas do Planalto, bairro com pouca infraestrutura instalada e historicamente constituído por sua maioria populacional ser de baixa renda.

\subsection{Setores em Continuidade}

São aquelas áreas que crescem em extensão com os tecidos urbanos existentes. Elas são, sobretudo, localizadas, nos municípios de Parnamirim e São Gonçalo do Amarante, municípios conurbados com Natal. No caso da RMN pode-se identificar aquelas áreas formadas pela continuidade da malha urbana de Natal sobre Parnamirim e parte de São Gonçalo do Amarante, além de trecho do município de Extremoz que também é um município de alta integração com a cidade-polo da RMN, conforme os dados do IBGE (2010) permitem evidenciar. No caso de Extremoz destaca-se o empreendimento Jardins de Extremoz I/II/III/IV, o qual encontra em uma área de transição entre Setor em Continuidade pela proximidade com a cidade-polo por meio da BR 101 que divide os dois municípios, Figura 4.

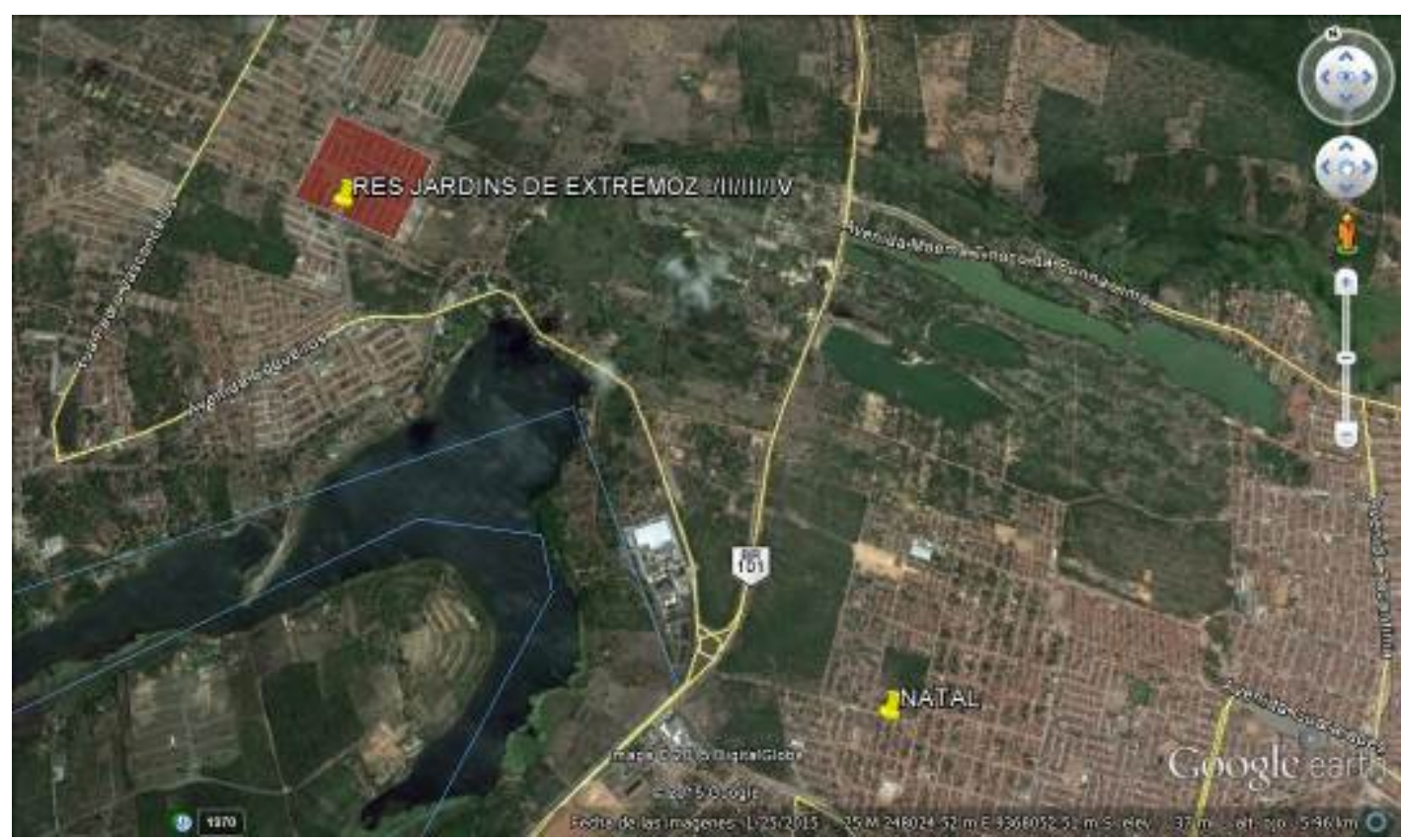

Figura 3: Localização do condomínio horizontal Jardins de Extremoz I/II/IIII/IV. Fonte: Google Earth, 2015. 
Os dados revelam, Quadro 2, que no setor em continuidade há 65 empreendimentos, desses $80 \%$ situam-se no município de Parnamirim. Isto retrata um processo de ocupação considerável e de formação de novos tecidos urbanos destinados a uso residencial nesse município.

\begin{tabular}{|l|l|l|l|l|}
\hline $\begin{array}{l}\text { Sistema Urbano em } \\
\text { continuidade }\end{array}$ & $\begin{array}{l}\text { Faixa 01 (Até R\$ } \\
1.600,00)\end{array}$ & $\begin{array}{l}\text { Faixa 02 (Até R\$ } \\
5.000,00)\end{array}$ & Município \\
\hline $\begin{array}{l}\text { Quantidade } \\
\text { (Empreendimentos) }\end{array}$ & 27 & 38 & Total: 65 \\
\hline $\begin{array}{l}\text { Quantidade (Unidades } \\
\text { Habitacionais) }\end{array}$ & 9.423 & 6.058 & Total: 15.481 \\
\hline
\end{tabular}

Quadro 2: Empreendimentos enquadrados no Setor em Continuidade.

Fonte: Elaboração própria, 2015. Base de dados: E-sic, 2012/2013/2014.

A mancha da expansão de ocupação pela zona urbana está presente de maneira marcante nesse setor em continuidade. Ressalta-se que $65 \%$ dos empreendimentos urbanos, se localizam nesse setor em continuidade. O que se configura a ocupação dos tecidos urbanos dos municípios de Extremoz, São Gonçalo do Amarante, Macaíba e Parnamirim por meio da atuação do PMCMV configurando o espraiamento do território metropolitano por meio de novas ocupações.

\subsection{Setores Segregados}

São aqueles separados dos núcleos urbanos, ou por distâncias superiores de 0,5 a 1Km, de infraestruturas de primeira ordem, de topografia ou pela passagem de um eixo fluvial principal. Observou-se que este setor abrange os municípios do entorno de Natal - Extremoz, São Gonçalo do Amarante, Macaíba, São José do Mipibu e Nísia Floresta, porém desses, os únicos que possuem os empreendimentos do PMCMV são os dois últimos. Esses imóveis localizam-se em áreas onde o preço são mais acessíveis, por isso há predominância de empreendimentos destinados a faixa 01 de renda, correspondente até $R \$ 1.600,00$. Estes se localizam mais próximos das áreas periurbanas, porém desarticulados com os núcleos urbanos dos municípios. São as áreas de transição entre os setores em continuidade e os setores dispersos.

Reforça-se aqui que esse termo segregado, utilizado por Font (2012) na sua análise sobre a Região Metropolitana de Barcelona é considerado igualmente aqui, como uma variável espacial.

\begin{tabular}{|l|ll|ll|l|}
\hline $\begin{array}{l}\text { Setores do Sistema } \\
\text { Urbano }\end{array}$ & $\begin{array}{l}\text { Faixa 01 (Até } \\
1.600,00)\end{array}$ & R\$ & $\begin{array}{l}\text { Faixa 02 (Até } \\
5.000,00)\end{array}$ & Município \\
\hline $\begin{array}{l}\text { Quantidade } \\
\text { (Empreendimentos) }\end{array}$ & 03 & - & & Total: 03 \\
\hline $\begin{array}{l}\text { Quantidade } \\
\text { (Unidades } \\
\text { Habitacionais) }\end{array}$ & 550 & - & Total: 550 \\
\hline
\end{tabular}

Quadro 3: Empreendimentos enquadrados no Setor Segregado.

Fonte: Elaboração própria, 2015. Base de dados: E-sic, 2012/2013/2014.

Pode-se constatar que dentre todos os setores analisados da RMN esse é o que apresenta menor representatividade, ou seja, em se tratando de tecidos urbanos, apresenta-se pouca expressividade de modificação a partir da atuação pelo capital imobiliário residencial do PMCMV.

\subsection{Setores Dispersos}

São aquelas áreas que se localizam longe dos grandes eixos urbanos metropolitanos e se situam nos espaços abertos a planície litorânea, e/ou perto das áreas de proteção, áreas essas que dentro do contexto metropolitano, correspondem as zonas rurais e as periféricas dos municípios da RMN que por sua vez situamse distantes da cidade-polo Natal, sendo esta a diferença entre o setor segregado analisado anteriormente. Enquadra-se neste setor todos os empreendimentos, correspondente a 47\% (82 unidades) do total de 174 analisados, localizam-se nas áreas periféricas dos municípios da RMN, exceto Parnamirim, Natal e Extremoz.

Ressalta-se que São Gonçalo enquadrou-se neste setor pela grande quantidade de empreendimentos rurais, os quais são desarticulados com a cidade-polo e o restante da RM. Portanto, insere-se também nestes setores, o município de Vera Cruz (ver Figura 1), que apresenta empreendimentos nas zonas rurais (Figura 5). Um agravante a essa falta de integração viária é que tais empreendimentos não disponibilizam de ligações adequadas ao sistema viário, isto é, para estes empreendimentos não é exigido vias de acesso, as referidas 
Leis preveem apenas subsidiar a produção ou reforma de imóveis aos agricultores familiares e trabalhadores rurais sem, contudo, viabilizar melhorias no entorno e no acesso aos mesmos.

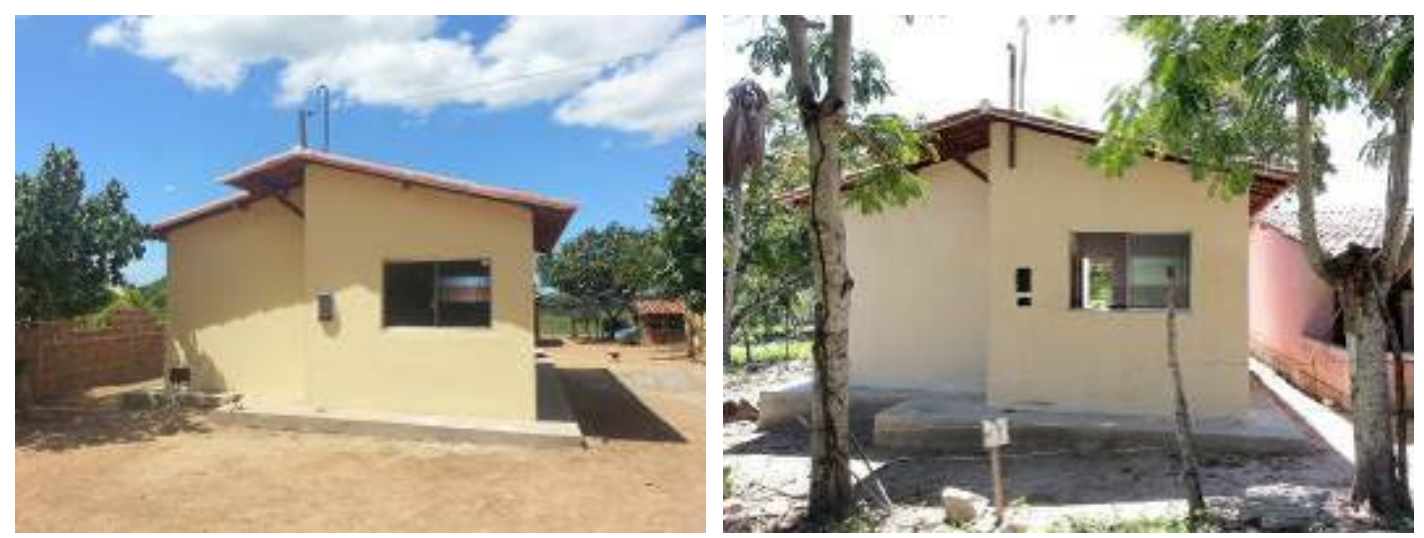

Figura 4: Exemplos de empreendimentos rurais no município de São Gonçalo do Amarante.

Fonte: Ciranda Social, 2013.

Aqui se verifica o fenômeno da dispersão urbana mais claramente, o qual está presente nos fragmentos dos tecidos urbanos que compõem este setor. A desarticulação com seus núcleos urbanos se efetiva pelas longas distâncias até os mesmos. Por se tratar em sua maioria de áreas rurais, essas distâncias ultrapassam a extensão de $3 \mathrm{Km}$ até chegar à no núcleo urbano consolidado do município. A predominância nessas áreas é de empreendimentos voltados a faixa de renda 01 (até $R \$ 1.600,00$ ), onde a tipologia predominante é horizontal, portanto, configura-se também o processo de espraiamento do tecido urbano metropolitano. O solo rural, muitas vezes, se confunde com o solo urbano, porém formam-se grandes extensões de terras desconectadas do restante da cidade, Quadro 4.

\begin{tabular}{|l|ll|ll|l|}
\hline $\begin{array}{l}\text { Sistema Urbano } \\
\text { Disperso }\end{array}$ & $\begin{array}{l}\text { Faixa 01 (Até R\$ } \\
1.600,00)\end{array}$ & $\begin{array}{l}\text { Faixa 02 (Até R R } \\
5.000,00)\end{array}$ & Município \\
\hline $\begin{array}{l}\text { Quantidade } \\
\text { (Empreendimentos) }\end{array}$ & 82 & & - & & Total: 82 \\
\hline $\begin{array}{l}\text { Quantidade } \\
\text { (Unidades } \\
\text { Habitacionais) }\end{array}$ & 1.796 & & - & & Total: 1.796 \\
\hline
\end{tabular}

Quadro 4: Empreendimentos enquadrados no Setor Disperso.

Fonte: Elaboração própria, 2015. Base de dados: E-sic, 2012/2013/2014.

Observou-se que estes setores em continuidade estão localizados nos tecidos periurbanos entre Natal, Parnamirim e São Gonçalo do Amante, isto é, na Área Metropolitana Funcional ${ }^{9}$, os quais apresentam alta integração segundo o Censo 2010 do IBGE. Os outros dois setores de segregação e dispersão estão presentes na Área Metropolitana Funcional, apenas em São Gonçalo do Amarante. Este município é o único da RMN que apresenta quase todos os setores analisados, excetuando-se o setor integrado que abrange somente a cidade-polo Natal.

O panorama que se tem como resultado desse processo é a inserção urbana desarticulada com os núcleos urbanos dos municípios e com o restante da cidade tendo em vista a implantação das unidades habitacionais distantes do acesso aos bens, serviços e equipamentos. Nesse caso, constatou-se a omissão do poder municipal do compromisso de instalação ou de ampliação dos equipamentos e serviços relacionados a educação, saúde, lazer e transporte público. Ou seja, essas áreas desprovidas de infraestrutura, acabaram por constituir os fragmentos de glebas urbanas e rurais que consolidaram o processo de fragmentação espacial e reafirmaram as desigualdades socioespaciais presentes na estruturação da RMN. Uma vez que, onde havia estoques de terras urbanizadas o preço do imóvel era mais caro e ocorreu concentração de ocupação por famílias da faixa 02 de renda e, vice-versa, onde existia solo ainda por urbanizar, o preço de terra era mais baixo e houve maior concentração de ocupação por famílias da faixa 01 de renda, ocupando as terras mais longínquas, consequentemente, mais baratas e sem infraestrutura implantada.

\footnotetext{
${ }^{9}$ Conforme Font (1997, p.16) define para o caso da Região Metropolitana de Barcelona, como sendo: "Un sistema urbano polinuclear extendido por el territorio, fragmentado y discontinuo, en el que recientemente la población y una buena parte de la actividad productiva y de los servicios personales tienden a difundirse por el territorio alterando el modelo tradicional de aglomerado o ciudad continua con dependencias casi exclusivas del núcleo central, en un territorio jerarquizado pero más interactivo y auto-organizativo y de gran heterogeneidad morfológica".
} 
A atuação do PMCMV na RMN, apesar da quantidade de oferta residencial, esta não se traduziu em maiores possibilidades de acesso a habitação. Em primeiro lugar, pelo tipo do produto final e a concentração territorial do mesmo em determinados bairros da cidade. Em segundo lugar, o simplismo, a falta de complexidade das formas urbanas e a repetição da homogeneidade vistas nos municípios da Área Metropolitana Funcional Natal, Parnamirim e São Gonçalo do Amarante - têm sido a monotonia dos projetos residenciais, dando lugar a um conglomerado estereotipado que permite situá-los em qualquer parte do território. A fazer uso de um conceito de Font (2012) pode-se dizer que esta "insularidade", isto é, os vários formatos de ilhas simbolizando os condomínios e conjuntos habitacionais espelhados ao longo do território, representando morfologias a parte das existentes nas cidades e esgarçando tecidos urbanos, contribuiu para o espraiamento do território metropolitano. Características como estas são dominantes na dinâmica do processo de urbanização capitalista verificada na atual configuração do território da RMN, como pode ser visto no Quadro 5.
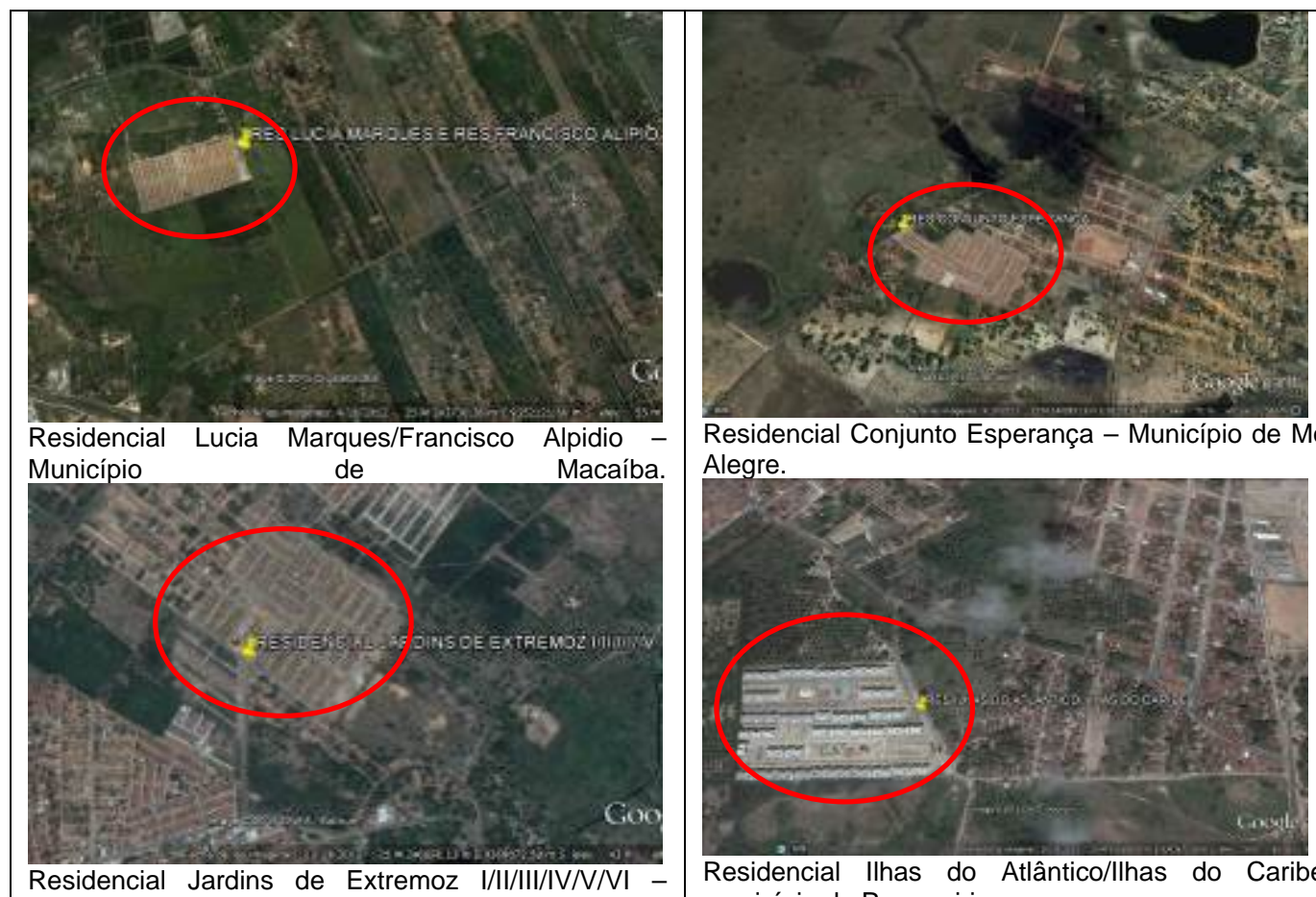
município de Extremoz.

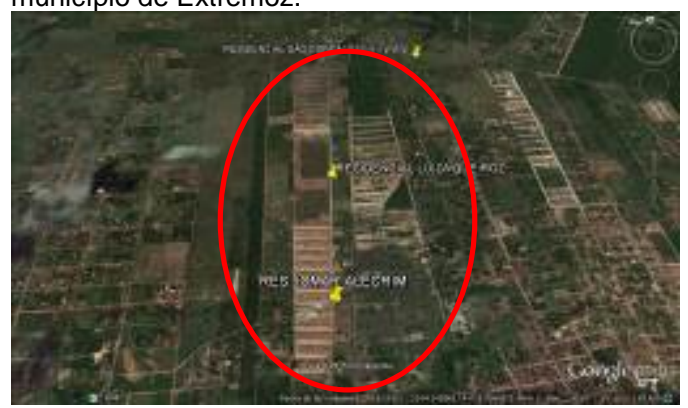

Residencial Jomar Alecrim/Luiza Queirozl São

Gonçalo I/II/III/IV/V/VI - Município de São Gonçalo do Amarante.

Residencial Conjunto Esperança - Município de Monte Alegre.

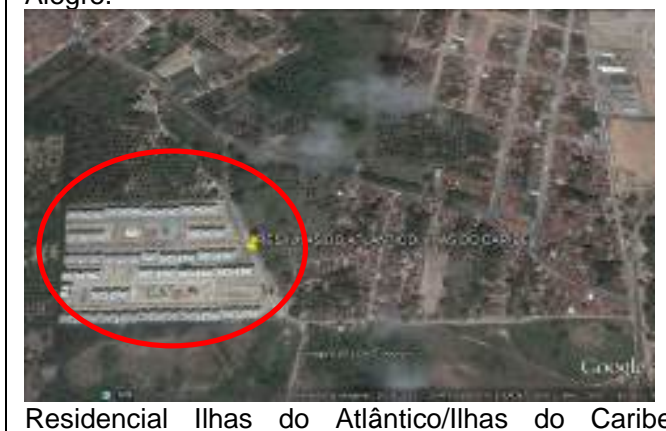

Residencial Ilhas do
município de Parnamirim.

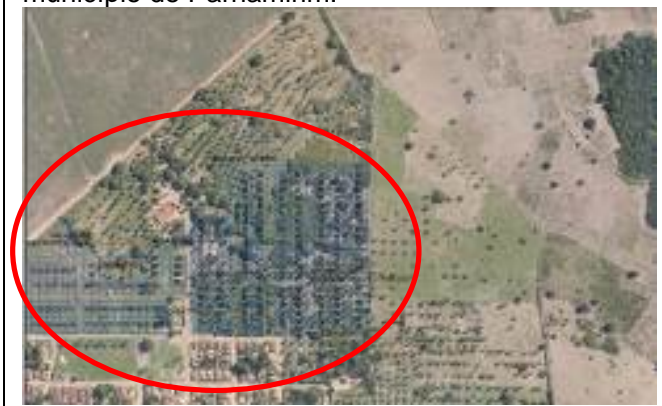

Residencial Monte Pascoal - Município de São José do Mipibu.

Quadro 5: Exemplos de alguns empreendimentos de diferentes formas urbanas na RMN.

Fonte: Elaboração própria, 2014. Base de Dados: Google Earth, 2014.

A leitura da espacialização do uso residencial produzido pelo PMCMV na RMN é feita da seguinte forma: no município de Parnamirim, se apresenta hoje o solo mais caro da RMN, depois de Natal. Ali estão sendo construídos condomínios-clubes (com área de lazer e entretenimentos internos ao empreendimento), condomínios destinados à faixa 02 de renda (até $\mathrm{R} \$ 5.000,00$ ), além de condomínios de casas de padrão alto, e de porte intermediário. Os destinados à faixa 01 de renda (até $R \$ 1.600,00$ ) apresentam tipologias conjugadas, seja por meio de casas unifamiliares ou de condomínios multifamiliares populares, localizandose distantes das franjas periféricas de Natal-Parnamirim, e com mais frequência nos outros municípios como Ceará-Mirim, Extremoz, Macaíba, São Gonçalo do Amarante e São José de Mipibu. Diante deste cenário, observa-se que os conjuntos habitacionais (formados pelas casas dos loteamentos), nos quais se encontra 
área de equipamento de lazer menor e com baixa qualidade no partido arquitetônico e urbanístico, se apresentaram mal conservados, cujos equipamentos coletivos e infantis se tornaram, em pouco tempo, um espaço deteriorado e com pouca arborização no tratamento paisagístico.

É nítida a tendência da delimitação dos setores do Sistema Urbano (integrado, em continuidade, segregado e disperso) e o espraiamento do território metropolitano a partir da cidade-polo Natal na direção das áreas periféricas dos municípios da RMN. Soma-se a isto, o processo de fragmentação do tecido urbano seguido da lógica ocupacional da urbanização desigual promovida pelo capital imobiliário residencial e consequentemente do valor do solo baseado na localização com relação a todas as variáveis aqui analisadas, conformando o território metropolitano ilustrado no modelo explicativo a seguir, Figura 8.

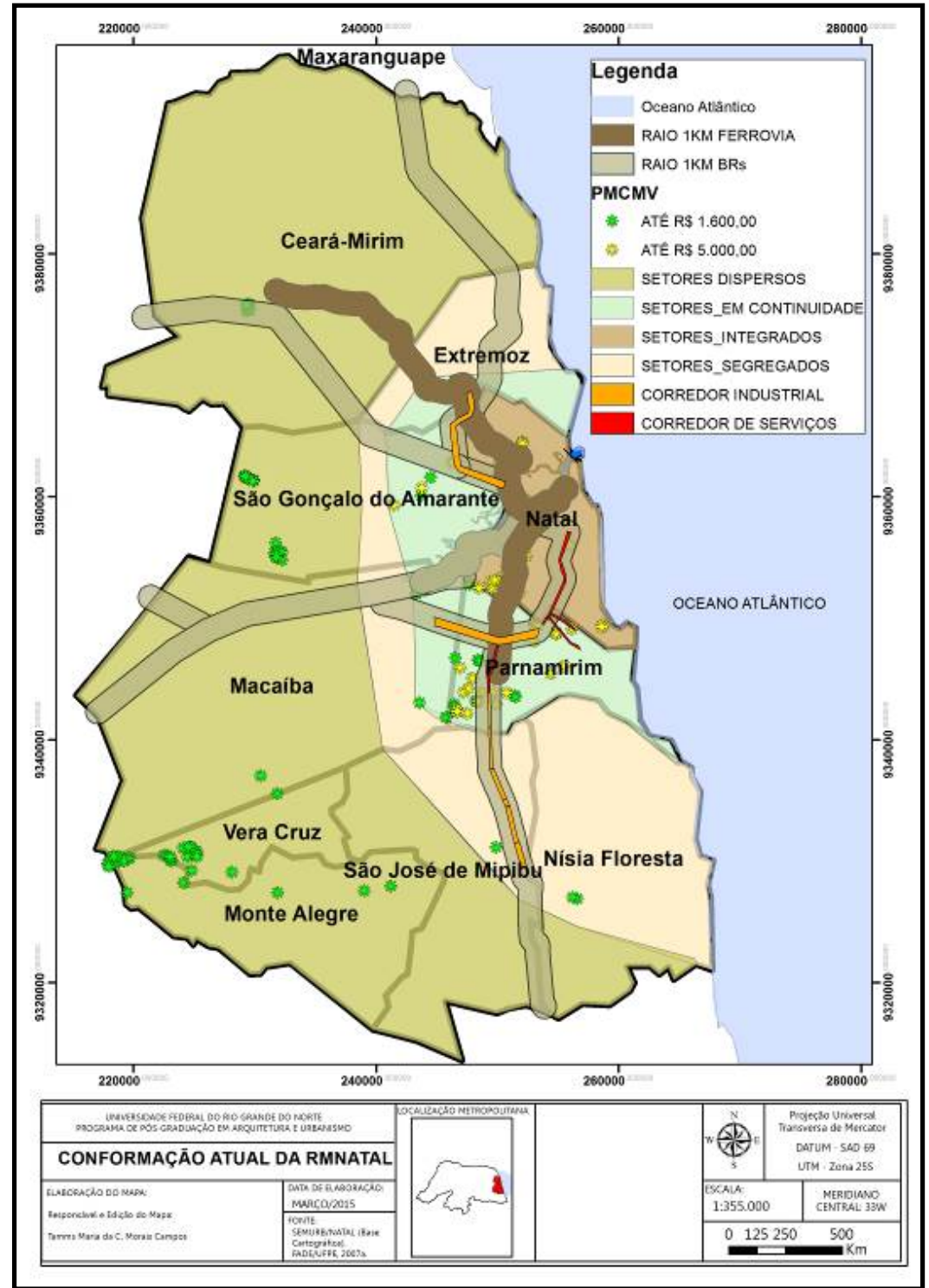

Figura 5: Representação da conformação atual da RMN.

Fonte: Elaboração própria, 2015.

Enfim, a esse processo que se manifesta por meio de todas essas formas e da confirmação de transformação dos tecidos urbanos vistos sob a ótica da análise espacial da (re)configuração da RMN, que foi denominado de "Urbanização Imobiliária Residencial", cuja definição se resume como sendo: "Processo que consiste no uso e na apropriação do território a partir da produção capitalista de atividades imobiliárias residenciais, sobretudo quando esta se manifesta em grande escala e se configura por meio de formas específicas de tecido urbano". 


\section{CONSIDERAÇÕES FINAIS}

Foi visto que a atual dinâmica imobiliária residencial promovida por ações do Estado e agentes promotores do solo urbano vêm configurando o processo de "Urbanização Imobiliária Residencial" na RMN. Tal processo é a forma mais atual da urbanização capitalista caracterizada por ser pontual e restrita, com diferenças em relação ao acesso à infraestrutura urbana onde o Estado agencia a promoção pública de infraestrutura favorecendo a mercantilização da cidade e promovendo o poder de apropriação do espaço pelo mercado através da lógica ocupacional capitalista. Essa relação de poder reproduziu desigualdades socioespaciais e aguçou o acionamento de um mercado de terra na RMN.

Diante dessa conjuntura e levando em consideração o aprofundamento das hipóteses, constatou-se, nesta pesquisa, algumas particularidades com relação a essa urbanização na RMN: a promoção de um crescente processo de periferização residencial com um claro predomínio da baixa densidade e de habitação unifamiliar nos municípios da RMN institucional que se distanciam de sua cidade-polo, principalmente no eixo norte representado por Ceará-Mirim e, sul pelos municípios de Vera Cruz, Monte Alegre, São José do Mipibu e Nísia Floresta. Nos casos dos municípios da Área Metropolitana Funcional (Natal, São Gonçalo do Amarante e Parnamirim), observou-se que seus tecidos urbanos apresentaram predominância de tipologias com alta densidade e habitação multifamiliar. Outra particularidade é a fragmentação dos tecidos metropolitanos vista a partir da morfologia resultante das inserções urbanas dos empreendimentos do PMCMV, a qual indicou o surgimento de "insularidades" que conformam o território espraiado e descontínuo, gerado tanto por processos como a extensificação, conceituada por Monte-Mor (1994), e a dispersão urbana como pela intensificação dos processos de urbanizações imobiliárias residenciais; aqui a forma de morar, representada por grandes empreendimentos condominiais, principalmente, constituídos por quarteirões introspectos e a falta de urbanidade do seu entorno. Indica uma frequente produção espacial na RMN, onde os aspectos morfológicos geram desigualdades socioespaciais no território metropolitano.

Assim onde há área urbanizada, essas se voltam para maior procura de lucro e maximização do uso do solo, favorecendo tipologias verticais voltadas para família com faixa de renda próxima a $R \$ 5.000,00$ produzindo em geral, áreas mais concentradas e compactas nas faixas periurbanas da Área Metropolitana Funcional. Onde tem solo urbano para ser parcelado, distante dos núcleos urbanos, se instalam tipologias horizontais que se voltam para famílias com renda a $\mathrm{R} \$ 1.600,00$. Resultando na existência de amplas áreas de dispersão ocupadas e caracterizadas por baixa densidade.

Foi observado que esta fragmentação do território juntamente com a espacialização dos setores por meio da descentralização progressiva de urbanizações decorrentes da dinâmica imobiliária residencial representadas por tipologias de conjuntos habitacionais (casas de loteamentos) e condomínios fechados (verticais e horizontais) foram desencadeadas por processos anteriores induzidos pela política habitacional do $\mathrm{BNH}-$ que em sua atuação no território da cidade-polo favoreceu a hierarquização socioespacial - e, pela produção imobiliária vinculada ao turismo - que promoveu o esgarçamento dos tecidos urbanos dos municípios litorâneos da RMN.

O cenário materializado por essa dinâmica territorial resultante também da atual produção habitacional de moradia configura, no território metropolitano, processos como a dispersão urbana que se apresenta com a predominância de morfologias bastante heterogêneas e a formação de tecidos urbanos fragmentados e desarticulados em relação a trama urbana das cidades já existentes. Isso comprova a ação feroz deste processo de urbanização gerado pela ação capitalista de produção do espaço em busca de acumulação de capital presente nas metrópoles brasileiras e consolidada no território da RMN.

Por meio da dinâmica de ocupação urbana produzida pela Urbanização Imobiliária Residencial e pela implantação dos empreendimentos do PMCMV, constatou-se que o território da RMN enquadrou-se, de acordo com metodologia adotada por Font (2012) para Barcelona, como segregado e disperso, abrangendo uma mancha de ocupação de $19 \%$ e $64 \%$ da área total metropolitana, respectivamente. Outro fato constatado é que o espraiamento do território da cidade-polo está se dando de maneira efetiva nos setores em continuidade que abrange os municípios da Área Metropolitana Funcional; Extremoz e Macaíba representa $11 \%$ da ocupação da RMN. Esse setor juntamente com o segregado, forma a $3^{\mathrm{a}}$ Coroa. Enquanto que a $2^{\mathrm{a}}$ Coroa, é constituída pela mancha de ocupação demarcada por ocupações de processos anteriores pelo auge do imobiliário turístico, mas que persiste recentemente e transita por todos os Setores Urbanos apresentando um formato linear em toda a extensão da costa litorânea. O fato de Natal representar a grande centralidade de serviços, comércios e demais atividades produtivas, juntamente com a expansão da ocupação promovida pela implantação dos conjuntos do BNH em seu território a qual favoreceu a instalação de áreas urbanizadas 
que permitiu o espraiamento ao restante da RMN, fez dessa cidade se constituir unicamente como um Setor integrado, representando uma área de $6 \%$, formando assim, a $1^{\text {a }}$ Coroa da mancha de ocupação metropolitana.

Pelas manchas dos setores foi possível comprovar a gradação do processo de desigualdade socioespacial e fragmentação urbana da RMN tendo como referência a distância ao núcleo das centralidades das atividades presentes na cidade-polo. Constatou-se que quando mais próximo de Natal mais frequente é a inserção urbana da faixa 02 de renda (até $R \$ 5.000,00$ ) e mais o valor do solo infraestruturado aumenta. À medida que vai se distanciando da cidade-polo, mais escassa vai ficando a infraestrutura, menor é o valor do solo e maior presença da faixa 01 de renda (até $\mathrm{R} \$ 1.600,00$ ). Assim, o processo de ocupação da RMN está cada vez mais atrelado à produção imobiliária residencial promovida pelo capital imobiliário que configurando um mosaico de "insularidades" no território, abrigando e distribuindo de forma desigual os condomínios, com estratégias de mercado voltadas para a instalação de uma gama de equipamentos de lazer e entretenimentos a fim de atenuar a baixa urbanidade, e os loteamentos, sendo cada vez mais considerados como lugares inóspidos por seus moradores, efeitos diretos da Urbanização Imobiliária Residencial.

Com toda essa discussão do modelo adotado pela Urbanização Imobiliária Residencial apresentada no decorrer deste artigo, detém-se aqui destacar uma reflexão sobre a cidade que se deseja viver e legar ao futuro, a cidade onde todos tenham igualdade de acesso à habitação, aos seus bens, serviços e infraestruturas urbanas. Contudo, deduz-se que os problemas decorrentes da fragilidade do acesso à habitação digna, à infraestrutura instalada, à mobilidade urbana da cidade, às questões socioambientais, ao direito à cidade e tantas outras matérias de interesse comum, é um desafio a vencer e ultrapassar os limites territoriais dos municípios e chegar ao plano metropolitano.

\section{BIBLIOGRAFIA}

CLEMENTINO, M. L., M. PESSOA, Z. S. (2009a). Natal: uma metrópole em formação. Natal: Educ.

- SOUZA, M. A. A. (coords.) (2009b). Como andam Natal e Recife. Rio de Janeiro: Letra Capital.

- (2015). FERREIRA, A. L. (orgs.). A metropolização de Natal em debate. Natal: transformações na ordem urbana. Rio de Janeiro: Letra Capital.

DEMATTEIS, G. (1998). Suburbanización y periurbanización, ciudades anglosajonas y ciudades latinas. En F. J. MONCLUS, La ciudad dispersa. Suburbanización y nuevas periferias. Barcelona: CCCB.

DUARTE, M. C. de S. et al. (2015). Política urbana na Região Metropolitana de Natal: o arcabouço normativo da metrópole funcional e institucional. Em: CLEMENTINO, M. L. M., FERREIRA, A. L. (orgs.). A metropolização de Natal em debate. Natal: transformações na ordem urbana. Rio de Janeiro: Letra Capital.

FERREIRA, A. L. (1996). De la producción del espacio urbano a la creación de territorios en la ciudad: un estudio sobre la constitución de lo urbano en Natal, Brasil. Tese de Doutorado en Geografia Humana. Espanha: Universitat de Barcelona.

FONT, A. A. (1997). Anatomía de una metrópoli discontinua: La Barcelona metropolitana. Paper Regió Metropolitana de Barcelona (9-19), Barcelona, Núm. 26, Gener.

- (2012). Patrons urbanístics de les ativitats econòmiques. Regió Metropolitana de Barcelona. Barcelona: Institut d`Estudis Territorials.

IBGE - INSTITUTO BRASILEIRO DE GEOGRAFIA E ESTATÍSTICA. (2010). Resultados Preliminares do Universo do Censo Demográfico. Rio de Janeiro: IBGE.

- (2011). Censo Demográfico 2010. Rio de Janeiro: IBGE.

MONTE-MÓR, R. L. (1994). Urbanização extensiva e novas lógicas de povoamento: um olhar ambiental. Em: SANTOS, M., SOUZA, M. A., SILVEIRA, M. L. (ed.). Território: globalização e fragmentação. São Paulo: Hucitec/Anpur. 
NATAL (RN). (2007). Governo do Estado do Rio Grande do Norte. Plano de Desenvolvimento Sustentável da Região Metropolitana de Natal - Natal Metrópole 2020. Produto 9 - Diagnóstico, Tendências, Cenários e Diretrizes. Recife: FADE/UFPE.

OBSERVATÓRIO DAS METRÓPOLES. (2012). Metropolização Turística: dinâmica e reestruturação dos territórios em Salvador, Recife, Fortaleza e Natal - estudos comparativos para o Nordeste (Núcleo RMN). Natal: Projeto INCT.

REIS, N. G.(2006). Notas sobre urbanização dispersa e novas formas de tecido urbano. São Paulo: Via das Artes.

SILVA, A. F. C.(2010). O litoral e a Metrópole. Dinâmica imobiliária, turismo e expansão urbana na Região Metropolitana de Natal-RN. Tese de Doutorado en Arquitetura e Urbanismo. Natal: Universidade Federal do Rio Grande do Norte.

-. (2012); FERREIRA, A. L. Imobiliário-Turístico no litoral nordestino: investimentos estrangeiros e impactos locais nas praias potiguares. Em: M. A. P. da FONSECA (org.). Segunda residência: Lazer e turismo. Natal: EDUFRN.

SPOSITO, M. E. B.(2007). Novas formas de produção do espaço urbano no Estado de São Paulo. Em: N. G. Reis; M. S. TANAKA (coord). Brasil - estudos sobre dispersão urbana. São Paulo: FAU-USP.

«Fuentes electrónicas»

http://www.ibge.gov.br/home/estatistica/populacao/censo2010 (Consulta: 05/05/2012). 